\title{
Characterizing surface defects in machine-planning of rubberwood (Hevea brasiliensis)
}

\begin{abstract}
Despite its extensive application in the furniture manufacturing industry throughout the South East Asian region, the machine-planing characteristics of rubberwood (Hevea brasiliensis) are not completely understood. In an effort to optimize the process, a series of experiments were undertaken using a Weinig 22A Unimat moulder (cutter-head rpm of 6000, cutter $\varnothing 120$ $\mathrm{mm}$ ) to produce machined rubberwood surfaces with differing pitch lengths ranging from 0.8 $\mathrm{mm}$ to $1.5 \mathrm{~mm}$, by altering the feed speed. The results showed that surfaces with a pitch length of cutter marks of $1.2 \mathrm{~mm}$ or more and a high knife rake angle were more prone to manifest machining defects, such as torn grain. This study shows that for machine planing of rubberwood the recommended cutter marks pitch length of $1.2 \mathrm{~mm}$, achieved with a knife rake angle of $20^{\circ}$, will ensure the highest resultant surface quality and processing yield.
\end{abstract}

